10-1987

\title{
Programs for Young Children: State Policy Options
}

University of Pennsylvania

Follow this and additional works at: https://repository.upenn.edu/cpre_policybriefs

Part of the Curriculum and Instruction Commons, Education Policy Commons, and the Elementary and Middle and Secondary Education Administration Commons

\section{Recommended Citation}

University of Pennsylvania. (1987). Programs for Young Children: State Policy Options. CPRE Policy Briefs.

Retrieved from https://repository.upenn.edu/cpre_policybriefs/59

This document was authored by the Consortium for Policy Research in Education, but no individual authors were identified.

View on the CPRE website.

This paper is posted at ScholarlyCommons. https://repository.upenn.edu/cpre_policybriefs/59

For more information, please contact repository@pobox.upenn.edu. 


\title{
Programs for Young Children: State Policy Options
}

\author{
Abstract \\ Young Children Face the States: Issues and Options for Early Childhood Programs by W. Norton Grubb is \\ summarized in this policy brief. The report discusses the many decisions state policymakers must make \\ as they seek to respond to needs of today's parents and children. It also describes the historical conflicts \\ that persist within the early childhood movement and the status of early childhood education policy \\ across the country. \\ Disciplines \\ Curriculum and Instruction | Education Policy | Elementary and Middle and Secondary Education \\ Administration

\section{Comments} \\ This document was authored by the Consortium for Policy Research in Education, but no individual \\ authors were identified. \\ View on the CPRE website.
}




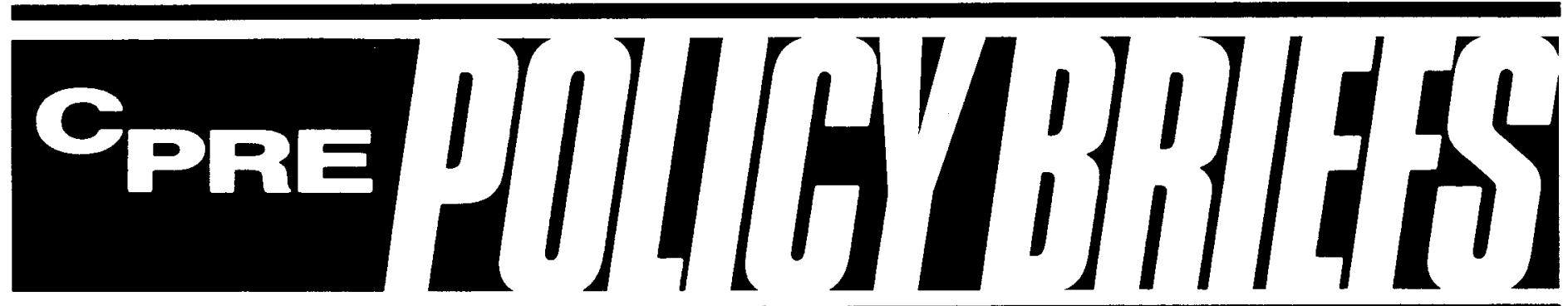

REPORTING ON ISSUES AND RESEARGH IN EDUGATION POLICY

\section{Programs For Young Children: State Policy Options}

The Issue of Providing Programs

For Very Young Children Is Fast Gaining High Political Visibility.

While federal support for such programs has declined over the last few years, current initiatives are coming from the states (see Table 1). Yet, state policymaking in the field of early childhood education is still in its infancy. State policymakers now have a rare opportunity to develop, almost from the start, an effective and coherent approach to early childhood education, according to a research report published by the Center for Policy Research in Education (CPRE).

Much confusion surrounds early childhood programs - their operational nature, their costs, their effects, their quality and even their basic objectivesespecially since most states have provided little of their own funding for early childhood programs and thus have little knowledge of this area.

Turf battles persist and the major professional communities with an interest in young children often confront each other over basic philosophical objectives and methodologies, as well as over economic issues associated with jobs and administrative control. Unless policymakers develop a coherent approach to these problems, the current interest in young children could easily fade without effective programs to show for all the effort. Or states could legislate programs that are at best, ineffective or at worst, harmful to children.

Young Children Face the States: Issues and Options for Early Childhood Programs by W. Norton Grubb is summarized in this policy brief. The report discusses the many decisions state policymakers must make as they seek to respond to the needs of today's parents and children. It also describes the historical conflicts that persist within the early childhood movement and the current status of early childhood education policy across the country.

The report does not attempt to prescribe a single "best" method of dealing with this issue. Rather, it provides a framework for setting goals. Once policymakers decide on the goals of early childhood programs in their own states, various elements - such as funding mechanisms, administrative structures and program requirements - can be tailored to reach those goals.

\section{Which Children Should Be Served... and In What Types of Programs?}

The goals of any early childhood policy are inextricably tied to the question of what populations should be served. Should programs be provided for 4-year-olds, 3-to-4-year-olds or even for infants? Should all children in a specified age group be eligible to attend programs or should enrollment be limited to children who speak little English or to those who are considered "at-risk?"

The importance of this question cannot be overstated. Most states have targeted at-risk children for their programs (see Table 1). But the best programs provide an integrated setting with children of various racial and socio-economic backgrounds, rather than segregating at-risk children from others. Moreover, while child care for low-income children has been a special concern, the amount and quality of child care available to children whose parents can afford to pay for it is also inadequate. 
And then there is the question of hours of operation. Most of the programs recently enacted by states are half-day preschool programs, administered by state departments of education and run by local school districts (see again, Table 1). But since twothirds of women with children under age 6 work full time, part-time programs are insufficient.

Program content and structure are also important considerations for policymakers. Should programs be organized like most elementary classrooms where the emphasis is on cognitive development in a structured, teacher-directed atmosphere? Or should they follow the model used by many independent child-care centers, one that is less structured and focuses more on the child's emotional and social development?

The conflict over structure and focus reflects basic differences in conceptions of learning, the role of par-

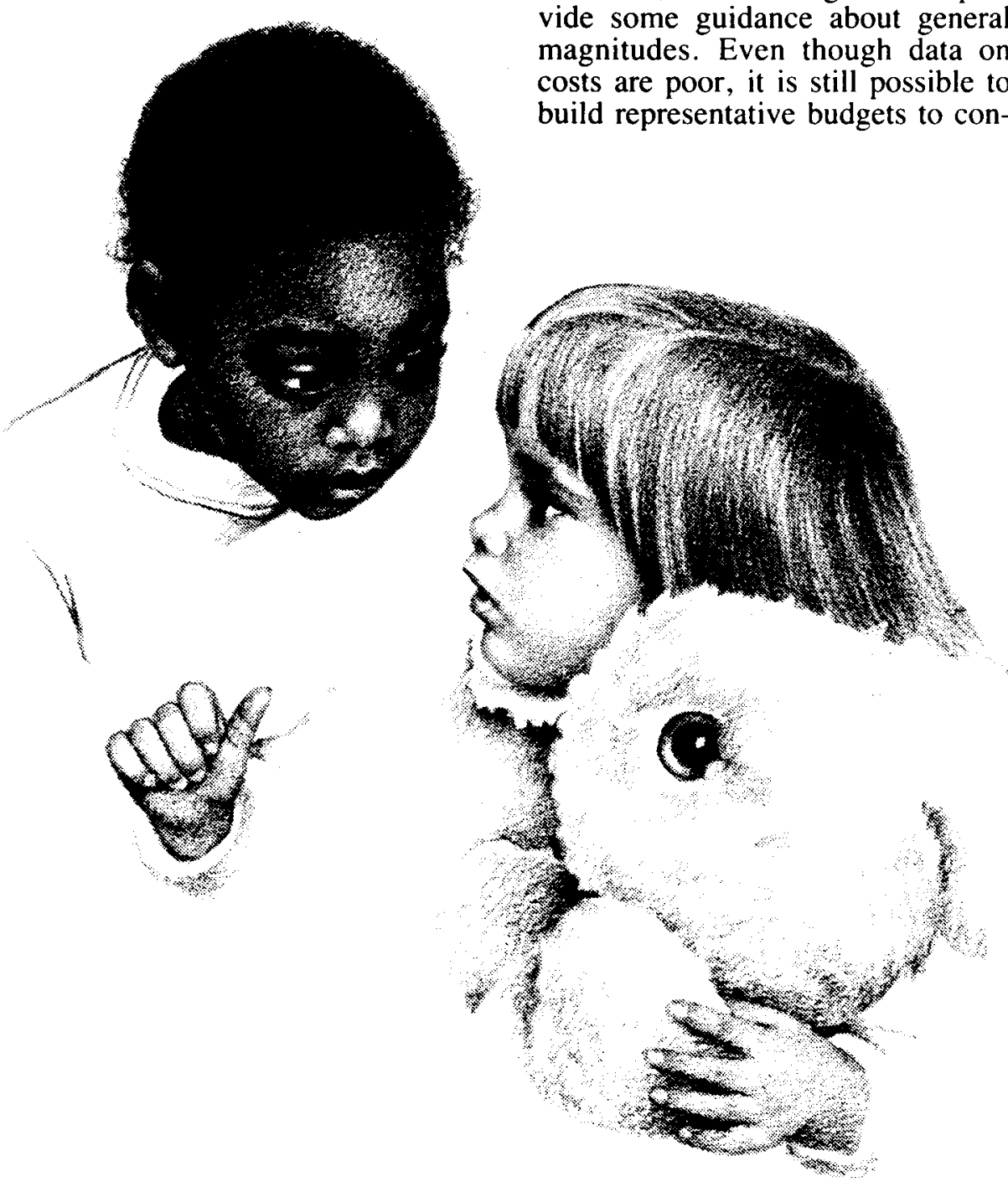

ents and teachers, teacher preparation and educational objectives. The problem for policymakers is to contain and narrow these differences with programs that permit flexibility and variety without allowing quality to vary intolerably. Although regulating content and quality is dif ficult, some direction is absolutely critical as a way to realize the benefits of exemplary programs.

\section{What Levels of Funding Will the Programs Receive... and In What Forms?}

Much of a state's early childhood policy will be shaped by decisions about funding. Given the wide variation in what teachers are paid, in adult-child ratios, in access to free or reduced-cost facilities, in volunteer resources, in the costs of living and in the extra services provided by programs, it is nearly impossible to say what a "typical" early childhood program might cost.

However, available figures can provide some guidance about general magnitudes. Even though data on costs are poor, it is still possible to build representative budgets to con-

\section{Another fiscal decision involves funding sources and mechanisms.}

One way to stretch state funds is to require local revenues to support some fraction of the total costs; but if this fraction is too high, few cities and school districts would want to participate. Another option would be to require parents to contribute to programs; especially on a sliding-fee basis. In this case, the design of the fee schedule may be crucial to the participation of families with different incomes.

States could fund early childhood programs in a number of ways. The simplest option would be to expand existing programs - either child-care programs funded through Title $\mathrm{XX} /$ SSBG funds or Head Start programs. This would add state revenues to existing federal funds, thereby allowing more low-income children to be served. State funds could also support services for more moderateincome children, allowing them to join existing programs by using a sliding-fee schedule. The simplicity of this alternative is obviously an advantage, since it would not be 
TABLE 1

\section{State Initiatives in Early Childhood Education}

\begin{tabular}{|c|c|c|c|c|c|}
\hline $\begin{array}{l}\text { POPULATION } \\
\text { SERVED }\end{array}$ & $\begin{array}{l}\text { HOURS OF } \\
\text { OPERATION }\end{array}$ & $\begin{array}{l}\text { NUMBERS SERVED/ } \\
\text { RESOURCES }\end{array}$ & RATIOS & $\begin{array}{c}\text { ECE } \\
\text { TRAINING }\end{array}$ & $\begin{array}{l}\text { METHOD OF } \\
\text { FUNDING }\end{array}$ \\
\hline
\end{tabular}

District of Columbia (enacted 1968)

$\begin{array}{llllll}\text { 4-year-olds } & \begin{array}{l}51 \text { full-day } 69 \\ \text { half-day }\end{array} & \begin{array}{l}3,300 \text { children } \\ \$ 2.9 \text { million }\end{array} & \begin{array}{l}1: 15 \text { (full-day) } \\ 1: 10 \text { (half-day) }\end{array} & \text { yes } & \begin{array}{l}\text { Local district funding } \\ \text { since 1982; previously }\end{array} \\ & & & \text { Chapter } 1 \text { funds }\end{array}$

Florida (begun 1986)

\begin{tabular}{|c|c|c|c|c|c|}
\hline $\begin{array}{l}\text { Migrant } \\
\text { children 3-4 }\end{array}$ & full-day & $\begin{array}{l}1,528 \text { children in } \\
100 \text { programs }\end{array}$ & $1: 10$ & no & $\begin{array}{l}\text { Some Ch. I funds. } \\
\text { Districts may subcontract } \\
\text { to private non-profits }\end{array}$ \\
\hline
\end{tabular}

Florida (enacted 1986; begun 1986-87)

Children 3-4; local option

$50 \%$ must be

8 pilot projects local option yes

disadvantaged

650 children;

$\$ 750,000$

(1986-87)

Illinois (enacted 1985; begun Jan. 1986)

\begin{tabular}{|c|c|c|c|c|c|}
\hline $\begin{array}{l}\text { Children 3-5 } \\
\text { "at risk" }\end{array}$ & half or full-day & $\begin{array}{l}7,4000 \text { children } \\
\text { in } 234 \text { districts } \\
12.1 \text { million }\end{array}$ & $\begin{array}{l}\text { none; } 1: 8 \\
\text { preferred }\end{array}$ & yes & $\begin{array}{l}\text { Project grants, up to one } \\
\text { per district; no local } \\
\text { match }\end{array}$ \\
\hline
\end{tabular}

Louisiana (enacted 1985; begun fall 1985)

\begin{tabular}{|c|c|c|c|}
\hline $\begin{array}{l}\text { 4-year-olds "at } \\
\text { risk" }\end{array}$ & mostly full-day & $\begin{array}{l}1,000 \text { children in } \\
37 \text { of } 66 \text { districts } \\
\$ 2.1 \text { million }\end{array}$ & $\begin{array}{l}1: 10 \text { with aide; } \\
1: 5 \text { without }\end{array}$ \\
\hline
\end{tabular}

Maine (enacted 1979)

4-year-olds

$\begin{array}{ll}\text { most half-day; } & 656 \text { children } \$ 1.6 \text { no limit } \\ \text { some } 2 & \text { million } \\ \text { days/week } & \end{array}$

no

Project grants to school districts

Project grants, 1-4 grants per district; no local match

Funded through the regular school aid program

Maryland (enacted 1979)

4-year olds half-day

2,225 children in

$1: 10$

yes

55 schools $\$ 2.25$

million

Project funding; schools selected based on low test scores

Massachusetts (enacted 1985); begun fall 1986)

\begin{tabular}{|c|c|}
\hline $\begin{array}{l}\text { Varied- } \\
\text { program } \\
\text { discretion }\end{array}$ & $\begin{array}{l}\text { half-day or } \\
\text { full-day }\end{array}$ \\
\hline
\end{tabular}

being yes

developed

(probably

$1: 10)$

Michigan (pilot projects Jan.-Sept. 1986)

$\begin{array}{lllll}\begin{array}{l}\text { 4-year olds "at } \\ \text { risk" }\end{array} & \begin{array}{l}\text { mostly } \\ \text { half-day }\end{array} & \begin{array}{l}400-500 \text { children } \\ \text { in } 23 \text { projects }\end{array} & 1: 10 & \text { no } \\ \text { New Jersey (since 1903) } & & & \text { no* } \\ \text { 4-year-olds } \quad \text { half-day } & \begin{array}{l}6,029 \text { children in } \\ 93 \text { districts }\end{array} & 1: 25 & \end{array}$


(TABLE 1 CONTINUED)

State Initiatives in Early Childhood Education

\begin{tabular}{|c|c|c|c|c|c|}
\hline $\begin{array}{l}\text { POPULATION } \\
\text { SERVED }\end{array}$ & $\begin{array}{l}\text { HOURS OF } \\
\text { OPERATION }\end{array}$ & $\begin{array}{l}\text { NUMBERS SERVED/ } \\
\text { RESOURCES }\end{array}$ & RATIOS & $\begin{array}{c}\text { ECE } \\
\text { TRAINING }\end{array}$ & $\begin{array}{l}\text { METHOD OF } \\
\text { FUNDING }\end{array}$ \\
\hline
\end{tabular}

New York State (enacted 1967)

$\begin{array}{llllll}4 \text {-year olds } & \text { mostly } & 9,300 \text { children in } & 1: 7.5 & \text { no } & \text { Project grants with } 11 \% \\ 90 \% & \text { half-day } & \begin{array}{l}75 \text { districts } \$ 20 \\ \text { million, } \\ \text { disadvantaged }\end{array} & \$ 2,600 / \text { child } & & \end{array}$

New York City (enacted 1986; implemented 1986-87)

\begin{tabular}{|c|c|c|c|c|c|}
\hline $\begin{array}{l}\text { Low-income } \\
4 \text {-year olds }\end{array}$ & half-day & $\begin{array}{l}2,600 \text { children } \\
\$ 6.7 \text { million }\end{array}$ & $1: 10$ & yes & $\begin{array}{l}\text { Project grants, with } \\
\text { high-need areas } \\
\text { targeted }\end{array}$ \\
\hline
\end{tabular}

Ohio (1985-86)

\begin{tabular}{|c|c|c|c|c|c|}
\hline 3-5 year-olds & $\begin{array}{l}2 \text { with } 2 \text { half- } \\
\text { days/week; } 1 \\
\text { full-day }\end{array}$ & $\begin{array}{l}120 \text { children in } 3 \\
\text { pilot projects }\end{array}$ & $1: 12$ & $\mathrm{no}^{*}$ & $\begin{array}{l}\text { Project grants to districts; } \\
\text { personnel costs paid } \\
\text { locally }\end{array}$ \\
\hline
\end{tabular}

Oklahoma (enacted 1980)

$\begin{array}{llllll}\text { 4-year-olds } & \begin{array}{l}\text { half-day or } \\ \text { full-day }\end{array} & \begin{array}{l}1,400 \text { children } \\ \text { in } 34 \text { programs } \\ \$ 1 \text { million }\end{array} & 1: 10 & \text { yes } & \begin{array}{l}\text { Project grants to school } \\ \text { districts }\end{array}\end{array}$

Pennsylvania (since 1965)

\begin{tabular}{|c|c|c|c|c|c|}
\hline 4-year-olds & $\begin{array}{l}\text { half-day or } \\
\text { full-day }\end{array}$ & unknown & no regs & unknown & $\begin{array}{l}\text { Regular state aid formula } \\
\text { for kindergartens used }\end{array}$ \\
\hline
\end{tabular}

South Carolina (enacted 1984)

\begin{tabular}{|c|c|c|c|c|c|}
\hline $\begin{array}{l}\text { 4-year-olds } \\
\text { with deficient } \\
\text { "readiness" }\end{array}$ & half-day & $\begin{array}{l}6,500 \text { children } \\
\$ 8.7 \text { million, } \\
\$ 1,053 / \text { child }\end{array}$ & $1: 10$ & yes & $\begin{array}{l}\text { Allocation to each district } \\
\text { based on students "not } \\
\text { ready" }\end{array}$ \\
\hline
\end{tabular}

Texas (enacted 1984; begun fall 1985)
4-year-olds, half-day low income or
35,000 children in 495 districts,
1:22 (with exemptions)
yes
Matching grant with state match based on local property value

Washington (enacted 1985)

\begin{tabular}{|c|c|c|c|c|c|}
\hline $\begin{array}{l}\text { 4-year-olds, } \\
\text { Head Start } \\
\text { eligibility }\end{array}$ & $\begin{array}{l}\text { mostly } \\
\text { half-day }\end{array}$ & $\begin{array}{l}1,000 \text { children } \\
\$ 2.9 \text { million, } \\
\$ 2,700 / \text { child }\end{array}$ & $1: 6$ & yes & $\begin{array}{l}\text { Funds to Head Start } \\
\text { agencies or schools; } \\
\text { priority to districts with } \\
\text { most at-risk children }\end{array}$ \\
\hline
\end{tabular}

\footnotetext{
* New early childhood credentials are being developed in Massachusetts and Ohio.

**In Louisiana a nursery or kindergarten certificate is preferred; in New Jersey most teachers have a nursery endorsement. SOURCES: Gnezda and Robinson 1985; Children's Defense Fund 1985; Schweinhart 1985.
} 


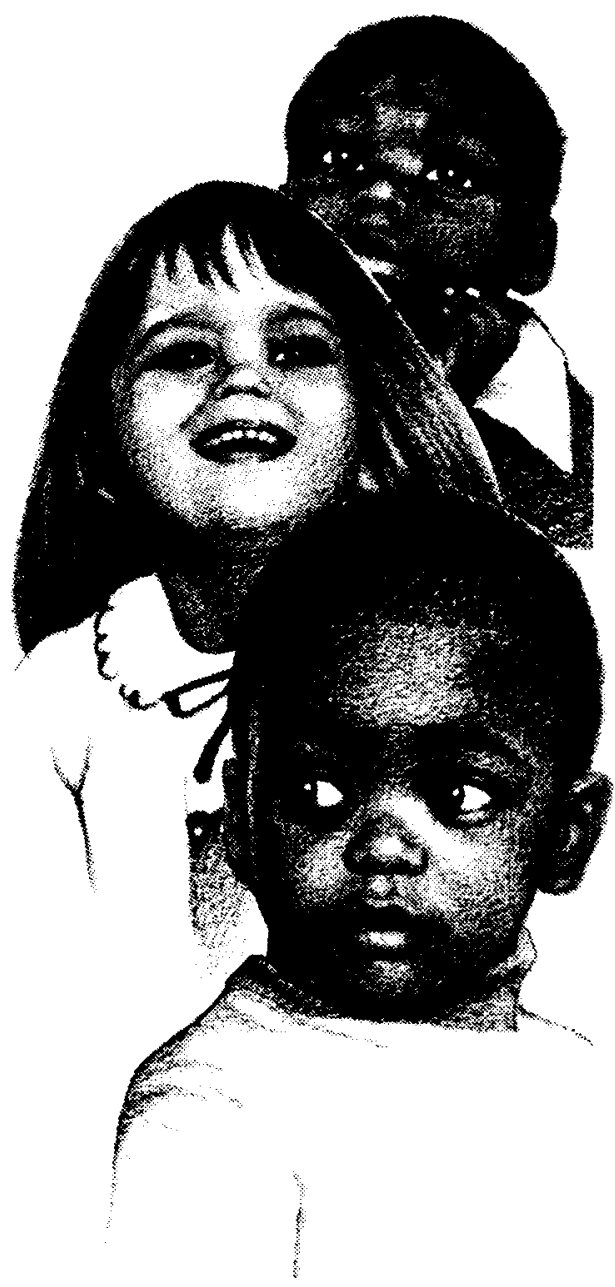

necessary to develop new administrative structures or program models.

\section{Additional Options For Funding Mechanisms Include:}

Expanding state tax credits: increasing the credit (or deduction) to individuals or to corporations.

$\square$ Project grants: eligibility can include school districts only, school districts with subcontracts allowed, or both school districts and community organizations.

$\square$ Formula funding: using existing formulas which fund only school districts, or creating new ones which allow schools, community organizations, cities, towns and counties to receive funds.

$\square$ Vouchers: to parents with unrestricted use, or to parents to be used for programs of specified quality.

$\square$ Multiprogram funding: such as the system used by California. This complex system allows eligible parents with different needs to choose among a range of programs.

Table 2

\section{Annual Costs Per Child Under Alternative Assumptions}

\begin{tabular}{|c|cccc|}
\hline $\begin{array}{c}\text { Ratio of } \\
\text { Teachers } \\
\text { to } \\
\begin{array}{c}\text { Pupils } \\
\text { No }\end{array}\end{array}$ & $\begin{array}{c}\text { Minimum } \\
\text { Wage }\end{array}$ & $\begin{array}{c}\text { Teacher Salaries } \\
\text { Current } \\
\text { Average } \\
\text { Childcare } \\
\text { Teacher }\end{array}$ & $\begin{array}{c}\text { Average of } \\
\text { Childcare } \\
\text { and } \\
\text { Elementary } \\
\text { Teachers }\end{array}$ & $\begin{array}{c}\text { Elementary } \\
\text { School } \\
\text { Teacher }\end{array}$ \\
\hline $1: 20$ & $\mathbf{\$ 7 , 3 0 0}$ & $\mathbf{\$ 1 2 , 8 0 0}$ & $\mathbf{\$ 1 8 , 6 0 0}$ & $\mathbf{\$ 2 4 , 5 0 0}$ \\
$1: 15$ & $\mathbf{\$ 1 , 1 6 8}$ & $\mathbf{\$ 1 , 4 4 3}$ & $\mathbf{\$ 1 , 7 3 3}$ & $\mathbf{\$ 2 , 0 2 8}$ \\
$1: 10$ & 1,290 & 1,656 & 2,043 & 2,436 \\
$1: 6$ & 1,533 & 2,083 & 2,663 & 3,253 \\
\hline 2,020 & 2,936 & 3,903 & 4,886 \\
\hline
\end{tabular}

This table also assumes the following fixed costs:

Other personnel costs

$\$ 373$

Space costs

$\$ 130$

Materials

$\$ 130$

Miscellaneous costs

$\$ 100$

These costs may vary, but the effect of their variation on total annual costs per child is much less than that of teacher salaries or teacher-pupil ratios.

Coordinating these programs is difficult and costs are relatively high, but the California model provides a vision of early childhood programs where flexibility and variety are enhanced.

\section{How Can High Quality in the Programs be Ensured?}

Once content, structure and funding choices are made, states must still make sure the programs are of good quality. Obviously, many of the choices about quality are made in legislative prescriptions about operating hours, adult-child ratios, teacher salaries, costs-per-child and other program components. For example, the decision to fund a half-day preschool, as many states have done, is also a decision not to expand day care that best meets the needs of working parents; a very low spending per child is implicitly a decision not to require programs of high quality.
Still another means of guiding the quality of early childhood programs is teacher certification. In this area, researchers and practitioners have reached one unanimous conclusion: teachers of young children must have specific training in early childhood development. According to this reasoning, a teacher with a community college certificate in early childhood education with a Child Development Associate credential would be preferable to someone with a B.A.-level elementary teaching certificate but without training in early childhood education.

Programs can also be enhanced by the actions of the state administering agency, through licensing requirements and technical assistance. All states license child-care facilities, although licensing is usually interpreted as ensuring that minimum health and safety standards are met, rather than enhancing the quality of the programs. Technical assist- 5 


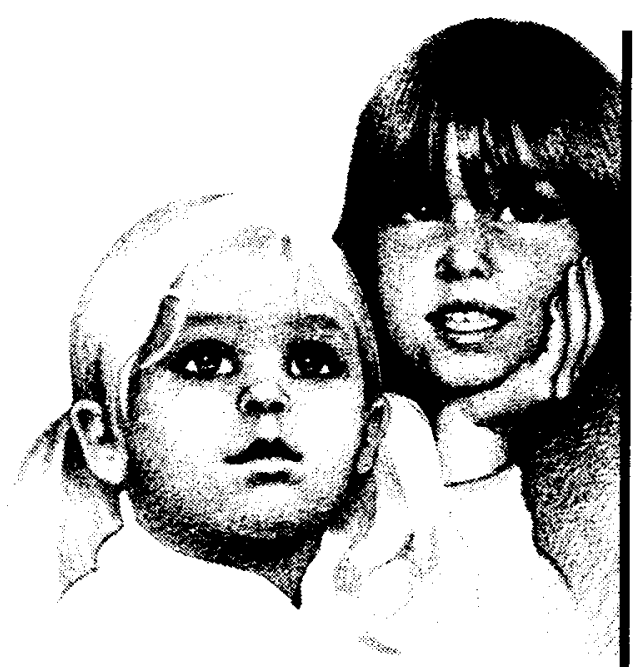

ance- providing consultation, workshops, information and access to experts in the field- is a better way to encourage development of good programs.

\section{Hopes For Children}

As an area of governmental concern, early childhood policy is still in its infancy. Most programs enacted thus far have been small and some of them seem to have been legislative accidents without much public support. Some of them have realized the worst fears of early childhood advocates while some of them are excellent models upon which to build. There is no dearth of options available to state policymakers. Rather, the problem is to decide on a state's goals and then devise the mechanisms to best accomplish them.

\section{CPRE Executive Board}

\section{DIRECTOR}

Susan H. Fuhrman

Eagleton Institute

of Politics

Rutgers, the State University

of New Jersey

\section{CHAIRMAN}

Robert Ray,

Former Governor of lowa;

President, Life Investors, Inc.

Cedar Rapids, lowa

John Brandl,

Senator

Minnesota State Senate

\section{Eugene Bardach,}

Professor

Graduate School of Public Policy

University of California at Berkeley

Alan Campbell,

Executive Vice President

ARA Services, Inc.

Philadelphia

Rev. Msgr. Paul Curran, Vicar for Catholic Education

Diocese of Philadelphia

Patrick Daly,

Teacher

Edsel Ford High School

Dearborn, Michigan

Arlene R. Penfield, School Board Member
Maxine Green,

Professor

Division of Philosophy,

Social Sciences and Education

Teachers College,

Columbia University

\section{Stephen Kaagan,}

Commissioner

Vermont State Department

of Education

Nancy J. Lee,

Teacher

Tigard High School

Tigard, Oregon

\section{Annette Morgan,}

Representative

Missouri House of Representatives

Thomas Payzant,

Superintendent,

San Diego Unified School District

Kenneth Hilton,

Member

Delaware State Board of Education

Terry Peterson,

Special Assistant to the President

Winthrop College

Columbia, South Carolina

Robert St. Clair,

Principal

Hopkins West Junior High School

Minnetonka, Minnesota

\section{The Center for Policy Research in Education (CPRE)}

CPRE unites the Eagleton Institute of Politics at Rutgers University, the RAND Corporation and the University of WisconsinMadison in a unique venture to improve the quality of schooling. Sponsored by the Office of Educational Research and Improvement of the U.S. Department of Education, CPRE conducts research on the implementation and effects of state and local education policies. By communicating its findings to policymakers, the Center attempts to contribute to the framing of education policies that will have a positive impact on children in 6 classrooms.

\section{CPRE's Research Activities Are Concentrated in Five Major Areas:}

- Curriculum and Student Standards

- Teacher Policies

- Educational Indicators and Monitoring

- New Roles and Responsibilities

- Evolution of the Reform Movement

In addition to conducting research in these areas, CPRE publishes research reports and briefs on a variety of education issues.* The Center also sponsors regional policy workshops for state and local policymakers.

For further information on CPRE, contact: Lynn McFarlane, Assistant Director for Communications, Center for Policy Research in Education, Eagleton Institute of Politics, Rutgers University, New Brunswick, New Jersey 08901; phone (201) 828-3872.

*The views expressed in CPRE publications are those of the individual authors and not necessarily those of the Center, its institutional members or the U.S. Department of Education. 